\title{
Lampau dan Sekarang: Analisis Kompetensi Absolut Dalam Perselisihan Hak Pada Pengadilan Agama
}

\author{
Xavier Nugraha, Fariz Rachman Iqbal, Ridho Firmansyah, \\ Giovanni Dinda Cahyawati \\ Universitas Airlangga Surabaya, Indonesia \\ E-mail: xavier.nugraha-2015@fh.unair.ac.id \\ doi) https://doi.org/10.32507/mizan.v4i2.799
}

\begin{abstract}
On Article 49 paragraph (1) of Law 7/1989, it is stated that the absolute competence of religious justice is limited to 6 (six) areas, namely marriage, inheritance, will, hibah, waqf, and shadaqah. Further, in Article 50 of Law 7/1989 it is stated, that if there is a dispute of rights related to the areas in Article 49 paragraph (1), then it must be decided in a state court. In its development, related to the absolute competence of this religious court underwent changes with the birth of Law 3/2006. In Law 3/2006, in addition to related to the addition of absolute competence, there is also the addition of Article 50 paragraph (2) which regulates related to the dispute of rights to be the absolute competence of religious justice. This research is a normative legal research with legal, conceptual, and case regulatory approaches. Based on this research, it was found that First, in Law 3/2006, there are 3 (three) new areas of absolute competence in religious justice into marriage, heirs, wills, grants, waqf, zakat, infaq, shadaqah, and shariqah economics and in Law 3/2006 has removed the existence of the right of choice in matters of inheritance for Muslims, so it must absolutely go through religious justice and Second, with the addition of Article 50 paragraph (2) of Law 3/2006, then in the case of disputes, then if the fellow Muslims, then can directly through the courts in the religious judicial environment. This, in order to realize a quick, simple, and lightweight trial.
\end{abstract}

Keywords: absolut competency, religious court, dispute of rights

\begin{abstract}
Abstrak
Pada Pasal 49 ayat (1) UU 7/1989, disebutkan bahwa kompetensi absolut dari peradilan agama terlimitasi pada 6 (enam) bidang, yaitu perkawinan, kewarisan, wasiat, hibah, wakaf, dan shadaqah. Dan dalam pasal 50 UU 7/1989 disebutkan, bahwa apabila terdapat sengketa hak yang berkaitan dengan bidang-bidang pada Pasal 49 ayat (1), maka harus diputus pada peradilan negeri. Dalam perkembangannya, terkait dengan kompetensi absolut dari peradilan agama ini mengalami perubahan dengan lahirnya UU 3/2006. Di dalam UU 3/2006, selain terkait dengan penambahan kompetensi absolut, juga terdapat penambahan Pasal 50 ayat (2) yang mengatur terkait dengan sengketa hak menjadi kompetensi absolut dari peradilan agama. Penelitian ini adalah penelitian hukum normatif dengan pendekatan peraturan perundang-undangan, konseptual, dan kasus. Berdasarkan penelitian ini ditemukan bahwa Pertama, pada UU 3/2006, terdapat 3 (tiga) bidang baru pada kompetensi absolut pada peradilan agama menjadi perkawinan, waris, wasiat, hibah, wakaf, zakat, infaq, shadaqah, dan ekonomi syari'ah dan di UU 3/2006 telah menghapus adanya hak opsi pada perkara waris bagi orang Islam, sehingga mutlak harus melalui peradilan agama dan Kedua, dengan adanya penambahan Pasal 50 ayat (2) pada UU 3/2006, maka dalam hal adanya sengketa, maka apabila para pihak sesama beragama Islam, maka bisa langsung melalui pengadilan pada lingkungan peradilan agama. Hal ini, dalam rangka mewujudkan peradilan yang cepat, sederhana, dan biaya ringan.
\end{abstract}

Keywords: kompetensi absolut, peradilan agama, peradilan umum, sengketa hak

* Naskah diterima tanggal: 13 September 2020, direvisi: 12 Oktober 2020, disetujui untuk terbit: 10 Desember 2020. 


\section{A. PENDAHULUAN}

Pasca amandemen ke-3 (tiga) terhadap Undang-Undang Dasar Tahun 1945 (UUD 1945), disebutkan pada Pasal 1 ayat (2) Undang-Undang Dasar Negara Republik Indonesia Tahun 1945 (UUD NRI 1945) ${ }^{1}$, bahwa "Kedaulatan berada di tangan rakyat dan dilaksanakan menurut Undang-Undang Dasar." Hal tersebut memiliki konsekuensi yuridis, bahwa sistem pemerintahan yang digunakan oleh Indonesia adalah sistem pemerintahan demokrasi. ${ }^{2}$ Sistem pemerintahan demokrasi ini sedikit berbeda dengan negara-negara lain yang menggunakan sistem serupa, karena sistem demokrasi yang digunakan adalah sistem demokrasi didasarkan pada hukum. Hal ini merupakan konsekuensi yuridis dari adanya Pasal 1 ayat (3) UUD NRI 1945 yang notabene merupakan lanjutan dari Pasal 1 ayat (1) UUD NRI 1945. ${ }^{3}$ Sistem demokrasi Indonesia yang sedikit berbeda ini disebut dengan democracy under the rule of law. ${ }^{4}$

Salah satu konsekuensi yuridis tersebut adalah adanya lembaga pengadilan (peradilan) yang bebas dan tidak memihak. Peradilan yang bebas dan tidak memihak ini memang sangat penting dalam negara hukum. Pentingnya sistem peradilan yang bebas dan tidak memihak ini, kemudian membuat para pembentuk UUD NRI 1945 melahirkan Pasal 24 ayat (1) UUD NRI 1945 yang berbunyi: “Kekuasaan Kehakiman merupakan kekuasaan yang merdeka untuk menyelenggarakan peradilan guna menegakkan hukum dan keadilan."

Dalam rangka untuk memastikan, bahwa peradilan di bawah Mahkamah Agung tersebut tidak membludak hanya pada 1 (satu) pengadilan saja dan untuk memastikan, bahwa hakim-hakim yang memutus sengketa tersebut memiliki spesifikasi atau keahlian pada sengketa yang dihadapinya, maka dibentuklah Pasal 24 ayat (2) UUD NRI 1945 yang mengatur bahwa: “Kekuasaan kehakiman dilakukan oleh sebuah Mahkamah Agung dan badan peradilan yang berada di bawahnya dalam lingkungan peradilan umum, lingkungan peradilan agama, lingkungan peradilan militer, lingkungan peradilan tata usaha negara, dan oleh sebuah Mahkamah Konstitusi." Dapat dilihat, bahwa sejatinya adanya pengklasifikasian menjadi 4 (empat) lingkungan peradilan tersebut dilakukan berdasarkan yurisdiksi atau lingkungan kewenangan peradilan tersebut.

Adanya Pasal 24 ayat (2) UUD NRI 1945 memberikan konsekuensi yuridis, bahwa dalam hal adanya sengketa, maka harus diajukan pada pengadilan yang tepat berdasarkan klasifikasinya tersebut. Adanya klasifikasi berdasarkan kewenangan

1UUD 1945 menunjukan konstitusi Indonesia sebelum amandemen, sementara UUD NRI 1945 menunjukan konstitusi Indonesia pasca amandemen, selebihnya lihat Xavier Nugraha, Risdiana Izzaty, and Annida Aqiila Putri, "Rekonstruksi Batas Usia Minimal Perkawinan Sebagai Bentuk Perlindungan Hukum" 3, no. 1 (2019): 40-54.

2 Mokhamad Abdul Aziz, "Pilkada Serentak Melalui DPRD: Sebuah Gagasan Mewujudkan Pilkada Demokratis Perspektif Pancasila Dan UUD 1945," Politik IndonesiaIndonesian Political Science Review 1, no. 2 (2016): 154-170.

3 Sunarno, “Negara Hukum Yang Demokratis," Wacana Hukum 10, no. 1 (2011): 41-62.

${ }^{4}$ Bagir Manan and Susi Dwi Harijanti, "Saat Rakyat Bicara: Demokrasi Dan Kesejahteraan," Padjajaran Jurnal Ilmu Hukum 1, no. 1 (2014): 1-18. 
mengadili berdasarkan yurisdiksi mengadili badan-badan peradilan ini yang disebut juga sebagai kompetensi absolut.

Dengan adanya pembagian berdasarkan kompetensi absolut, maka seharusnya sudah ada pembagian yang jelas terkait dengan kewenangan dari suatu pengadilan tersebut, akan tetapi ternyata pada kenyataanya masih terdapat perdebatan terkait dengan kompetensi absolut ini. Salah satu perdebatan terkait kompetensi absolut ini adalah antara pengadilan negeri dengan pengadilan agama terkait dengan sengketa hak.

\section{B. METODE PENELITIAN}

Penelitian ini adalah penelitian hukum yang dalam bahasa Inggris dikenal sebagai legal research. Penelitian hukum adalah suatu proses untuk menentukan aturan hukum, prinsip-prinsip hukum, maupun doktrin-doktrin hukum guna menjawab isu hukum yang dihadapi. ${ }^{5}$ Penelitian hukum yang digunakan dalam penelitian ini adalah penelitian hukum normatif atau doktrinal yang dilakukan dengan metode sesuai karakter yang khas dari ilmu hukum yang berbeda dengan ilmu sosial atau ilmu alam. ${ }^{6}$ Dalam penelitian hukum normatif ini, pendekatan yang digunakan adalah pendekatan peraturan perundang-undangan, pendekatan konseptual, dan pendekatan kasus.

\section{ANALISIS DAN PEMBAHASAN}

Dalam hukum keperdataan, terdapat salah satu asas fundamental yang dikenal sebagai asas personalitas. ${ }^{7}$ Asas personalitas ini memiliki makna, bahwa pemberlakuan hukum bergantung atau mengikuti subyek hukum atau orangnya, yakni warga negara di mana pun keberadaannya. ${ }^{8}$ Di Indonesia yang notabene merupakan negara yang sangat plural, membuat asas personalitas ini tidak hanya terlimitasi terkait pemberlakuan hukum berdasarkan kewarganegaraannya, namun juga berdasarkan aspek-aspek lain. Salah satu aspek lain yang mempengaruhi dalam penerapan asas personalitas ini adalah terkait dengan agama, salah satunya adalah personalitas keislaman.

Asas personalitas keislaman menyatakan bahwa hanya pemeluk agama Islam yang tunduk dan dapat ditundukkan kepada kekuasaan lingkungan peradilan agama. ${ }^{9}$ Asas ini juga termanifestasi di dalam Pasal 2 UU 50/2009. Jika melihat pada asas personalitas keislaman yang ada di dalam Pasal 2 UU 50/2009 menjelaskan bahwa tidak semua perkara bagi orang Islam diadili di peradilan agama, namun hanya

\footnotetext{
${ }^{5}$ Peter Mahmud Marzuki, Penelitian Hukum : Edisi Revisi (Jakarta: Kencana Prenada Media Group, 2017).

${ }^{6}$ Rosalinda, “Prinsip Kepentingan Terbaik Bagi Anak Dalam Perlindungan Hukum Anak Luar Kawin" (Universitas Airlangga, 2019).

7 Zulkarnain Suleman, “Asas Personalitas Keislaman Dalam Kompilasi Hukum Islam (KHI),” AlMizan 9, no. 1 (2013): 181-192.

${ }^{8}$ Adami Chazami, Pelajaran Hukum Perdata: Stelsel Pidana, Tindak Pidana, Teori- Teori Pemidanaan Dan Batas Berlakunya Hukum Perdata (Jakarta: Rajawali Press, 1991).

${ }^{9}$ Eka Susylawati, "Penerapan Asas Personalitas Keislaman Dalam Permohonan Pengangkatan Anak Di Kabupaten Pamekasan," Al-Ihkam: Jurnal Hukum \& Pranata Sosial 11, no. 2 (2017): 409.
} 
beberapa jenis perkara saja. Dengan demikian, dapat dimaknai, bahwa ketundukan personalitas seorang muslim kepada lingkungan Peradilan Agama, bukanlah ketundukan yang bersifat umum meliputi semua bidang hukum perdata. Akan tetapi ketundukan personalitas muslim kepadanya bersifat khusus pada perkara-perkara tertentu saja.

Di dalam UU 7/1989, ternyata terdapat celah yang membuat kompetensi absolut dari peradilan agama tersebut tidak bersifat mutlak. Hal ini disebabkan, karena di dalam UU 7/1989 dikenal dengan adanya hak opsi pada perkara waris. Hak opsi di dalam UU 7/1989 maka pada saat itu bisa dikatakan terdapat dualisme kompetensi absolut. Pada satu sisi, bisa saja meskipun orang tersebut beragama Islam, namun memiliki hukum waris perdata barat, maka otomatis yang berwenang adalah pengadilan negeri. Hal ini membuat pada saat itu menimbulkan keambiguitasan, karena orang-orang tersebut cenderung untuk memilih hukum waris yang menguntungkan mereka (yang memberikan lebih banyak harta waris). Hal inilah yang membuat pada saat itu dianggap hak opsi menimbulkan inkonsistensi pada peradilan agama. ${ }^{10}$

Adanya hak opsi ini, dianggap tidak konsisten dengan asas personalitas keislaman pada Pasal 2 UU 7/1989, karena pada Pasal 2 UU 7/1989 seolah-olah mewajibkan umat Islam tunduk pada hukum Islam, namun di satu sisi, dalam hal kewarisan memberikan hak untuk memilih apakah tunduk pada hukum Islam atau hukum perdata barat. ${ }^{11}$ Adanya inkosistensi ini, ternyata juga dirasakan oleh pembuat undang-undang, sehingga hak opsi ini kemudian dihapus dalam UU 3/2006. ${ }^{12}$

Dikarenakan hak opsi yang ada di UU 7/1989 sudah dihapus oleh UU 3/2006, menyebabkan orang beragama Islam wajib tunduk pada ketentuan hukum Islam yang ada pada UU 3/2006 secara menyeluruh dan tidak memiliki pilihan untuk tunduk pada hukum lain, seperti hukum perdata barat. Jika dikomparasikan antara UU 7/1989 dengan UU 3/2006, dapat dilihat terdapat 3 (tiga) aspek tambahan pada UU 3/2006, yaitu zakat, infaq, dan ekonomi syari'ah.

Jika melihat pada kompetensi absolut pada peradilan agama di dalam Pasal 49 Undang-Undang Nomor 3 Tahun 2006 Tentang Perubahan Atas Undang-Undang Nomor 7 Tahun 1989 Tentang Peradilan Agama (UU 3/2006) yang diubah dengan Undang-Undang Nomor 50 Tahun 2009 tentang Perubahan Kedua Atas UndangUndang Nomor 7 Tahun 1989 Tentang Peradilan Agama (UU 50/2009), disebutkan bahwa pengadilan agama bertugas dan berwenang memeriksa, memutus, dan menyelesaikan perkara di tingkat pertama antara orang-orang yang beragama Islam di bidang perkawinan, waris, wasiat, hibah, wakaf, zakat, infaq, shadaqah dan ekonomi syari'ah.

${ }^{10}$ Moh Sutomo, Syarifah Warohmah Marwiyah, and Nur Mawaddah, "Akar Historis Pengadilan Agama Masa Orde Baru," Yudisia 7, no. 2 (2016): 264-284.

${ }^{11}$ Mutaqien Dadan, “Hak Opsi Sebagai Kewarisan Dalam Tragedi Hukum,” Al Mawarid 7, no. 1 (1999): 34-44.

${ }^{12}$ Lina Kushidayati, "Hak Opsi Dan Hukum Waris Islam Di Indonesia," Al-Manahij 7, no. 1 (2013): 53-64. 
Kompetensi absolut dari peradilan agama yang terlimitasi pada 9 (sembilan) bidang tersebut seolah-olah melimitasi hak beragama umat muslim. Terdapat pandangan yang menganggap, bahwa umat Islam memiliki kewajiban untuk menjalankan syariat secara sempurna termasuk dibidang hukum pidana Islam (jinayah), sehingga seharusnya Pasal 49 UU 3/2006 diperluas termasuk dalam hukum pidana Islam. Terkait dengan pandangan ini, kemudian dibuatlah constitutional review di Mahkamah Konstitusi dengan nomor register perkara Nomor 19/PUU-VI/2008. ${ }^{13}$

Dalam Putusan Nomor 19/PUU-VI/2008, Mahkamah Konstitusi menolak hal tersebut, antara lain adalah:

\section{Kompetensi Absolut Dari Peradilan Agama Merupakan Open Legal Policy}

Mahkamah Konstitusi menjelaskan, bahwa terkait susunan, kedudukan, keanggotaan, dan hukum acara termasuk kompetensi absolut untuk masing-masing lingkungan peradilan yang berada di bawah Mahkamah Agung merupakan wewenang penuh dari legislator sebagaimana diamanatkan oleh Pasal 24 ayat (5) UUD NRI 1945. Adanya kebijakan yang membebaskan pembentuk undang-undang dalam menentukan suatu pasal yang tidak dilimitasi oleh UUD NRI 1945 yang dikenal juga sebagai open legal policy. ${ }^{14}$

\section{Hukum Islam Memang Sudah Menjadi Salah Satu Sumber Materiil Sebagai Bahan Peraturan Perundang-Undangan Formal}

Mahkamah Konstitusi menguraikan, bahwa hukum Islam sejatinya memang sudah menjadi salah satu sumber materil sebagai bahan peraturan perundangundangan formal. Terkait dengan kompetensi absolut yang diatur dalam Pasal 49 UU 3/2006 ini, ternyata sempat kembali diajukan constitutional review dalam perkara dengan nomor register 30/PUU-IX/2011. ${ }^{15}$ Dengan adanya 2 (dua) kali constitutional review terhadap Pasal 49 UU 3/2006 yang notabene merupakan kompetensi absolut dari peradilan agama dengan hasil 2 (dua) kali penolakan terhadap permohonan tersebut, maka tidak berlebihan untuk mengatakan, bahwa kompetensi absolut peradilan agama berdasarkan Pasal 49 UU 3/2006 adalah konstitusional.

\section{Sengketa Hak sebagai Kompetensi Absolut di Pengadilan Agama}

Terkait dengan kompetensi absolut dari pengadilan agama memang telah diatur di dalam Pasal 49 UU 3/2006, akan tetapi, ternyata pada praktiknya masih terdapat kebingungan pada kompetensi absolut antara pengadilan agama dengan pengadilan lain, yaitu pengadilan negeri. Pasal tersebut dilanjutkan oleh Pasal 50 yang mengatur bahwa apabila terdapat sengketa hak, maka hal tersebut merupakan kompetensi absolut pengadilan negeri, bukan pengadilan agama.

13 Alfitri, "Putusan Mahkamah Konstitusi Sebagai Tafsiran Resmi Hukum Islam Di Indonesia," Jurnal Konstitusi 11, no. 2 (2014): 297-314.

${ }^{14}$ Iwan Satriawan and Tanto Lailam, "Open Legal Policy Dalam Putusan Mahkamah Konstitusi Dan Pembentukan Undang-Undang," Jurnal Konstitusi 16, no. 3 (2019): 559.

${ }^{15}$ Melissa Crouch, "Constitutionalism, Islam and the Practice of Religious Deference: The Case of the Indonesian Constitutional Court," Australian Journal of Asian Law 16, no. 2 (2016): 1-15. 
Perkara ini berawal dari diajukannya gugatan oleh M. Ali Basjah, seorang pengawas harta milik Baitulmaal Mukmin Lhong terhadap M. Daud bin K. Sarong. M. Ali Basjah selaku penggugat mendalilkan, bahwa M. Daud bin K. Sarong menguasai aset yang seharusnya milik Baitulmaal Mukmin Lhong. M. Ali Basjah menjelaskan, bahwa aset yang didaku oleh M. Daud bin K. Sarong tersebut adalah aset dari Baitulmaal Mukmin Lhong yang diperoleh dari almarhum Lim Mamad yang notabene pada saat itu tidak mempunyai wali yang sah. M. Daud bin K. Sarong menolak dalil dari penggugat tersebut dan tetap bersikukuh, bahwa aset itu adalah miliknya. Adapun alasan dari M. Daud bin K. Sarong untuk mengakui aset tersebut adalah karena dia adalah wali nasab dari almarhum Lim Mamad. Adanya permasalahan tersebut yang kemudian melahirkan sengketa hak antara M. Ali Basjah, seorang pengawas harta milik Baitulmaal Mukmin Lhong selaku penggugat terhadap M. Daud bin K. Sarong selaku tergugat. ${ }^{16}$

Penggugat memang mengajukan gugatan pada pengadilan negeri, akan tetapi hakim pada pengadilan tinggi dalam Putusan Pengadilan Tinggi Banda Aceh Nomor 51/1969 Pdt Tanggal 14 Desember 1971 mendalilkan, bahwa adanya gugatan tersebut bukan merupakan kewenangan dari pengadilan negeri, melainkan pengadilan agama. Terkait dengan putusan tersebut, kemudian direvisi oleh hakim dalam Putusan MA No. 613K/SIP/1972. Hakim berpendapat, bahwa gugatan yang diajukan atas penguasaan tanpa hak atas harta Baitulmaal adalah menjadi wewenang lingkungan pengadilan umum dan bukan menjadi wewenang pengadilan agama. Dari putusan Mahkamah Agung ini, maka jelas hakim berpendapat bahwa dalam hal sengketa hak, maka harus diputus terlebih dahulu oleh pengadilan negeri.

Jika dianalisis, sejatinya memang putusan MA No. 613K/SIP/1972 bisa dibilang koheren dengan Pasal 50 UU 7/1989 yang notabene hakim mendasarkan adanya sengketa hak yang memang merupakan kompetensi absolut dari pengadilan negeri. Adapun beberapa putusan lain yang koheren dengan Pasal 50 UU 7/1989, yaitu Putusan Mahkamah Agung Nomor 132K/Pdt/1993. Dalam perkara ini, penggugat mengajukan sengketa pembagian warisan orang yang beragama Islam yang diajukan ke pengadilan umum. Tergugat yang memperoleh gugatan tersebut kemudian mengajukan eksepsi, dengan dalil bahwa pengadilan negeri tidak berwenang mengadili perkara warisan bagi yang beragama Islam sebab hal tersebut berada dalam yurisdiksi pengadilan agama berdasarkan Pasal 49 ayat (1) UU 7/1989.

Eksepsi yang diajukan oleh tergugat tersebut, kemudian ditolak oleh hakim dengan dasar, bahwa pengadilan negeri memang berwenang, karena dalam gugatan ini terdapat permasalahan sengketa hak dalam penentuan waris. Dengan dasar tersebut, maka hakim memutuskan bahwa perlu diputus terlebih dahulu adanya sengketa hak tersebut, baru diputus di pengadilan agama terkait dengan pembagian warisannya.

Adanya sengketa hak yang menjadi kompetensi absolut dari pengadilan negeri berdasarkan Pasal 50 UU 7/1989 dalam perkembangannya ternyata tidaklah bersifat

16 Soeroso R., Yurisprudensi Hukum Acara Perdata Bagian 1 Tentang Kompetensi Kewenangan Pengadilan (Jakarta: Sinar Grafika, 2011). 
mutlak. Hal ini disebabkan, karena pada UU 3/2006 yang notabene perubahan dari UU 7/1989 terdapat pengaturan tambahan, yaitu pada Pasal 50 ayat (2) yang berbunyi: "A pabila terjadi sengketa hak milik sebagaimana dimaksud pada ayat (1) yang subjek hukumnya antara orang-orang yang beragama Islam, objek sengketa tersebut diputus oleh pengadilan agama bersama-sama perkara sebagaimana dimaksud dalam Pasal 49." Berdasarkan Pasal 50 ayat (2) UU 3/2006, maka dapat dilihat bahwa terdapat penambahan kompetensi absolut pada peradilan agama terkait dengan sengketa hak antara umat Islam. Maka, jika dianalisis, sejatinya adanya penambahan kompetensi absolut pada Pasal 50 ayat (2) UU 3/2006 pada peradilan agama adalah karena politik hukum peradilan Indonesia yang semakin mengarah pada sistem peradilan yang cepat, sederhana, dan biaya ringan.

Berikut adalah gambaran perbedaan sengketa hak sebelum dengan sesudah Pasal 50 ayat (2) UU 3/2006.

\section{Gambar 1. Alur Sengketa Hak Sebelum Pasal 50 ayat (2) UU 3/2006}

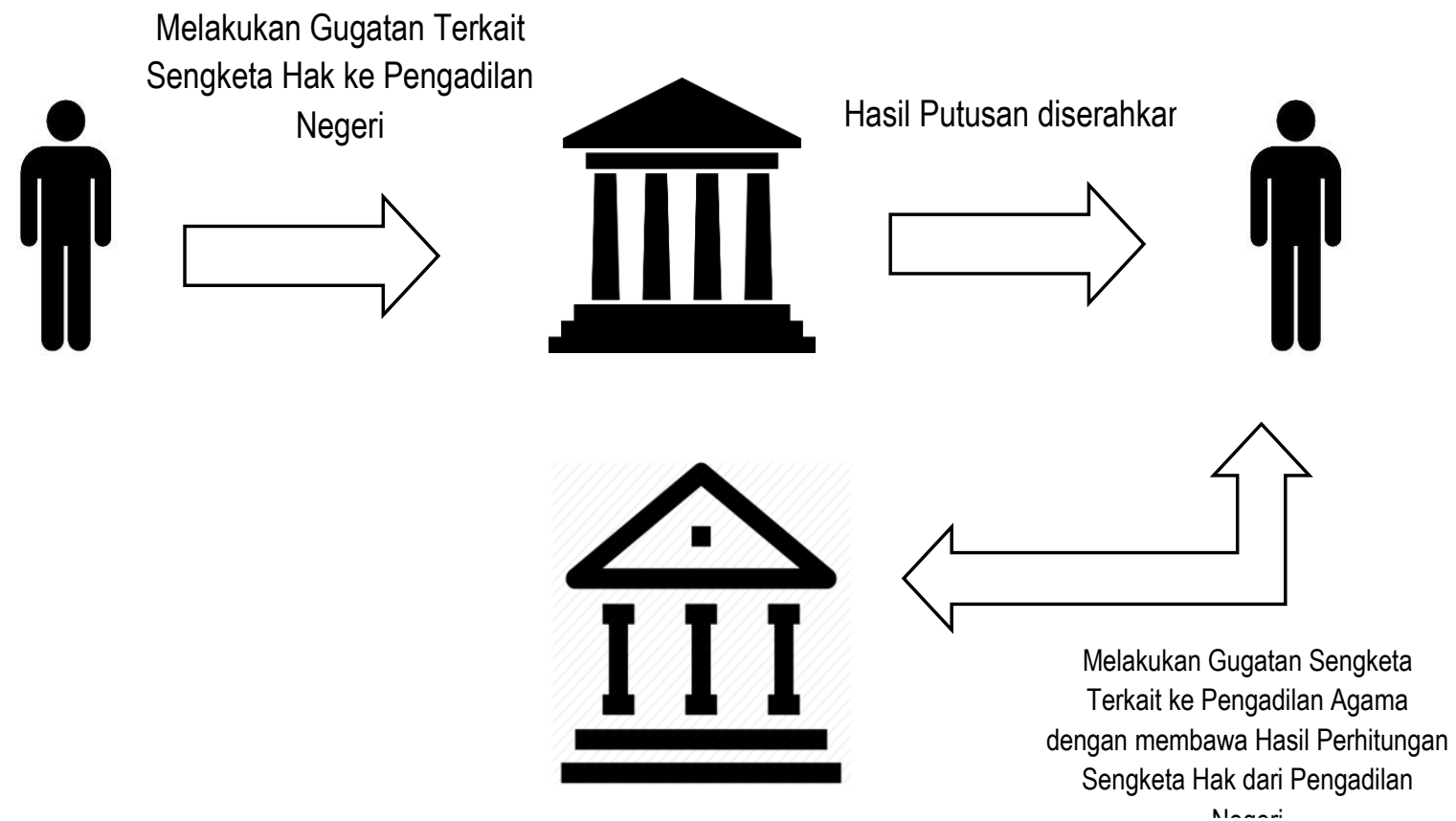

Gambar 2. Alur Senaketa Hak Setelah Pasal 50 avat (2) UU 3/2006
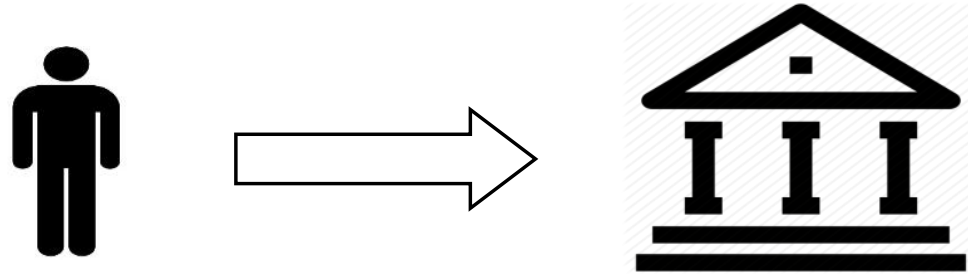

Langsung Melakukan Gugatan Terkait Sengketa Hak dan Sengketa Terkait ke Pengadilan Agama Apabila Sama-sama Beragama Islam 
Sumber: Dikelola Dari Berbagai Sumber Oleh Penulis

\section{KESIMPULAN}

Terdapat perubahan kompetensi absolut pada peradilan agama di dalam UU 7/1989 dan UU 3/2006. Dulu, pada UU 7/1989, kompetensi absolut pada peradilan agama terlimitasi pada 6 (enam) bidang, yaitu perkawinan, kewarisan, wasiat, hibah, wakaf, dan shadaqah. Bahkan, pada UU 7/1989, masih dikenal hak opsi pada perkara waris yang notabene bisa memilih antara peradilan negeri atau peradilan agama, sehingga tidak bisa mengatakan, bahwa terkait waris bagi pemeluk Islam adalah sepenuhnya kompetensi absolut dari peradilan agama. Dalam perkembangannya, pada UU 3/2006, terdapat 3 (tiga) bidang baru pada kompetensi absolut pada peradilan agama menjadi perkawinan, waris, wasiat, hibah, wakaf, zakat, infaq, shadaqah, dan ekonomi syari'ah dan di UU 3/2006 telah menghapus adanya hak opsi pada perkara waris bagi orang Islam, sehingga mutlak harus melalui peradilan agama.

Terkait dengan sengketa hak, juga terdapat perubahan di dalam UU 7/1989 dan UU 3/2006. Dulu, pada UU 7/1989, jika terdapat sengketa dengan hal-hal yang berkaitan dengan Pasal 49 ayat (1) UU 7/1989, maka harus diselesaikan terlebih dahulu di pengadilan pada lingkungan peradilan umum. Dalam perkembangannya, pada UU 3/2006 dengan adanya penambahan Pasal 50 ayat (2), maka apabila para pihak sesama beragama Islam, maka bisa langsung melalui pengadilan pada lingkungan peradilan agama. Hal ini, dalam rangka mewujudkan peradilan yang cepat, sederhana, dan biaya ringan.

\section{REFERENSI}

Adami, Chazami. Pelajaran Hukum Perdata: Stelsel Pidana, Tindak Pidana, Teori- Teori Pemidanaan Dan Batas Berlakunya Hukum Perdata. Jakarta: Rajawali Press, 1991.

Alfitri. "Putusan Mahkamah Konstitusi Sebagai Tafsiran Resmi Hukum Islam Di Indonesia."

Konstitusi 11, no. 2 (2014): 297-314.

Aziz, Mokhamad Abdul. "Pilkada Serentak Melalui DPRD: Sebuah Gagasan Mewujudkan Pilkada Demokratis Perspektif Pancasila Dan UUD 1945." Politik IndonesiaIndonesian Political Science Review 1, no. 2 (2016): 154-170.

Crouch, Melissa. "Constitutionalism, Islam and the Practice of Religious Deference: The Case of the Indonesian Constitutional Court." Australian Journal of Asian Law 16, no. 2 (2016): 1-15.

Dadan, Mutaqien. “Hak Opsi Sebagai Kewarisan Dalam Tragedi Hukum.” Al Mawarid 7, no. 1 (1999): 34-44.

Gumbira, Seno Wibowo. "Problematika Peninjauan Kembali Dalam Sistem Peradilan Pidana Pasca Putusan Mahkamah Konstitusi Dan Pasca SEMA RI No. 7 Tahun 
2014 (Suatu Analisa Yuridis Dan Asas-Asas Dalam Hukum Peradilan Pidana)." Jurnal Hukum E Pembangunan 46, no. 1 (2016): 106.

Hantoro, Novianto M. “Kajian Yuridis Pembentukan Undang-Undang Tentang Dewan Perwakilan Rakyat Republik Indonesia.” Negara Hukum 3, no. 2 (2012): 154-180.

Harahap, M. Yahya. "Berbagai Permasalahan Formil Dalam Gugatan Perdata." Varia Peradilan, Majalah hukum Ikahi, 1993.

- - - . Hukum Acara Perdata Tentang Gugatan, Persidangan, Penyitaan, Pembuktian, Dan Putusan Pengadilan. Edisi Kedu. Jakarta: Sinar Grafika, 2017.

Hutchinson, Terry. Researching and Writing in Law. Sydney: Lawbook Co, 2002.

Konstitusi, Mahkamah, and Republik Indonesia. Naskah Komprehensif Perubahan UUD Buku VI Kekuasaan Kehakiman. Vol. 53, 2010.

Lina Kushidayati. “Hak Opsi Dan Hukum Waris Islam Di Indonesia.” Al-Manahij 7, no. 1 (2013): 53-64.

Manan, Bagir, and Susi Dwi Harijanti. "Saat Rakyat Bicara: Demokrasi Dan Kesejahteraan." Padjajaran Jurnal Ilmu Hukum 1, no. 1 (2014): 1-18.

Marzuki, Peter Mahmud. Penelitian Hukum: Edisi Revisi. Jakarta: Kencana Prenada Media Group, 2017.

- - -. "Penelitian Hukum." Yuridika 16, no. 1 (2001): 103.

Muabezi, Zahermann Armandz. "Negara Berdasarkan Hukum (Rechtsstaats) Bukan Kekuasaan (Machtsstaat)." Jurnal Hukum dan Peradilan 6, no. 4 (2017): 421-446.

Muhammad, Mukmin. "Independensi Yudisial Sebagai Pilar Dari Suatu Negara Hukum." Meraja Journal 1, no. 1 (2018): 1-8.

Nugraha, Xavier, Risdiana Izzaty, and Annida Aqiila Putri. "Rekonstruksi Batas Usia Minimal Perkawinan Sebagai Bentuk Perlindungan Hukum” 3, no. 1 (2019): 4054 .

Nugraha, Xavier, John Eno Prasito Putra, and Krishna Darari Hamonangan Putra. "Analisa Daluarsa Gugatan Pembatalan Perjanjian Akibat Adanya Penyalahgunaan Keadaan (Misbruik Van Omstandigheiden)." Galuh Justisi 8, no. 1 (2020): 54-72.

R., Soeroso. Yurisprudensi Hukum Acara Perdata Bagian 1 Tentang Kompetensi Kewenangan Pengadilan. Jakarta: Sinar Grafika, 2011.

Rosalinda. "Prinsip Kepentingan Terbaik Bagi Anak Dalam Perlindungan Hukum Anak Luar Kawin." Universitas Airlangga, 2019.

Satriawan, Iwan, and Tanto Lailam. "Open Legal Policy Dalam Putusan Mahkamah Konstitusi Dan Pembentukan Undang-Undang." Jurnal Konstitusi 16, no. 3 (2019): 559.

Sunarno. “Negara Hukum Yang Demokratis.” Wacana Hukum 10, no. 1 (2011): 41-62. 
Susylawati, Eka. "Penerapan Asas Personalitas Keislaman Dalam Permohonan Pengangkatan Anak Di Kabupaten Pamekasan." Al-Ihkam: Jurnal Hukum $\mathcal{E}$ Pranata Sosial 11, no. 2 (2017): 409.

Sutomo, Moh, Syarifah Warohmah Marwiyah, and Nur Mawaddah. "Akar Historis Pengadilan Agama Masa Orde Baru." Yudisia 7, no. 2 (2016): 264-284.

Wahyono, Juanda, and Widya N. Rosari. “The Implementation Of Constitutional Court Decision Number: 93/PUU-X/2012 In Disputessettlement Of Syariah Bank Financing At The Court For Religionaffairs Of Bengkulu City." Bengkoelen Justice 7, no. 2 (2012).

Zaman, Muhammad Rutabuz. "Mendudukkan Kompetensi Absolut Peradilan Agama Dalam Sengketa Lelang Eksekusi Hak Tanggungan Pada Bank Syariah." Jurnal Studi islam Miyah 14, no. 2 (2018): 148-159.

Zulkarnain Suleman. "Asas Personalitas Keislaman Dalam Kompilasi Hukum Islam (KHI)." Al-Mizan 9, no. 1 (2013): 181-192. 